\title{
INTERKULTURALNI SADRŽAJI KAO POLAZIŠTE NASTAVE GLAZBE U EUROPSKIM OPĆEOBRAZOVNIM ŠKOLAMA
}

\author{
Amir Begić, Jasna Šulentić Begić \\ Umjetnička akademija u Osijeku, Sveučilište \\ Josipa Jurja Strossmayera u Osijeku, Hrvatska \\ abegic@uaos.hr; jsulentic-begic@uaos.hr
}

Primljeno: 18. 12. 2017

\begin{abstract}
Razvoj interkulturalne kompetencije pojedinca postao je nužnošću, a suvremena škola mora ići ukorak s vremenom i zbivanjima kojima smo okruženi. Odgoj mlade osobe sposobne da učinkovito djeluje $i$ živi u modernom društvu podrazumijeva i razvoj interkulturalne kompetencije svakog učenika. Nastava glazbe svakako je područje u kojemu se može razvijati interkulturalna kompetencija učenika. Preduvjet je interkulturalno koncipiran kurikulum, interkulturalni sadržaji u udžbenicima kao i primjeri različitih glazbenih tradicija sa svih kontinenata predviđeni za slušanje u nastavi glazbe. Stoga se ovim radom željelo utvrditi jesu li nacionalni, predmetni i školski kurikulumi kao i sadržaji udžbenika i pripadajućih im CD-a u dvanaest europskih država (Hrvatska, Mađarska, Slovenija, Austrija, Njemačka, Češka, Švicarska, Italija, Bosna i Hercegovina, Francuska, Engleska i Finska) zasnovani na interkulturalizmu. Rezultati istraživanja pokazali su da je nastava glazbe, posebice gimnazijska, još uvijek nedovoljno usmjerena na upoznavanje glazbe različitih kultura što je velika prepreka interkulturalnom odgoju učenika kojemu moramo težiti.
\end{abstract}

Ključne riječi: interkulturalni odgoj, nastava glazbe, osnovna škola, gimnazija, kurikulum

\section{Uvod}

Globalizacijski procesi, migracijska kretanja i sve naglašenija multikulturalnost suvremenih društava nameću potrebu za interkulturalno kompetentnom osobom koja će biti sposobna nositi se sa svim životnim izazovima. Društva postaju sve više interkulturalna i napuštaju shva- 
ćanja o dominantnim kulturama te na taj način omogućuju ljudima da slobodno oblikuju svoj identitet obogaćujući ga utjecajima različitih kultura (Drandić, 2010). Interkulturalizam izaziva i budi našu osnovnu ljudskost i umanjuje nejednakosti i različitosti naglašavajući sličnosti (Dei, 2000, u: Bradley, 2007). Danas se interkulturalizam javlja kao nova filozofija i nova praksa u višekulturnim društvima. Kod interkulturalizma prije svega je riječ o razumijevanju i prihvaćanju različitosti među ljudima i kulturama koje svijet čine takvim kakav jest (Previšić, 2009).

Sve ubrzaniji razvoj različitih i brojnih novih medija povezao je i najudaljenije dijelove svijeta. Potreba za razvojem interkulturalne kompetencije pojedinca postala je nužnošću. Multikulturalna Europa transformira se u interkulturalnu i očita je potreba za kompetencijama koje olakšavaju komunikaciju i razumijevanje među pripadnicima različitih kultura (Mrnjaus i Rončević, 2012). Suvremena škola mora ići ukorak s vremenom i zbivanjima kojima smo okruženi. Odgoj mlade osobe sposobne da učinkovito djeluje i živi u modernom društvu podrazumijeva i razvoj interkulturalne kompetencije svakog učenika. Odgoj kritičke osobe koja je u stanju isto tako kritički promišljati, ali iz različitih kulturnih perspektiva, jedan je od ciljeva interkulturalnog odgoja. To nije samo promjena kurikuluma ili neka dodatna aktivnost. To je proces koji teži drugačijim stavovima, novim pristupima i novim temeljima transformacije društva (Gorski, 2001, u: Tarman I. i Tarman B., 2011). Uvođenje elemenata interkulturalizma u multikulturalnim zajednicama nužno je kako bi učenici razvijali osjećaj poštovanja prema različitim kulturama (Izgarjan, Markov i Prodanović-Stankić, 2013).

Za interkulturalni odgoj i obrazovanje važna je didaktička i metodička osmišljenost i isplaniranost nastavnog procesa. Međutim, interkulturalizam u nastavi zahtijeva više od tradicionalnog pristupa koji podrazumijeva suho prenošenje nastavnih sadržaja.

»Umjesto fiksiranja programa, strogih zahtjeva svake nastavne jedinice, stalne brige za ocjenu i rezultat, nastavnik se više usmjerava na atmosferu među djecom, na toleranciju u mišljenjima i posredovanje među razlikama.« (Previšić, 1987, 311)

Ipak, ishodište interkulturalne nastave nalazi se u nacionalnim i školskim kurikulumima, odnosno u nastavnim planovima i programima. To je prvi preduvjet interkulturalnog odgoja u današnjoj nastavi 
koji mora biti ispunjen kako bi se stvorile pretpostavke za implementaciju interkulturalizma u nastavi.

\section{Interkulturalni kurikulum i nastava glazbe}

Posljednjih desetljeća aktualizirao se razvoj nacionalnih kurikuluma u europskim zemljama. Pojedine zemlje, manje ili više uspješno, a često i uz brojne reforme, nastoje konstruirati kurikulum koji bi zadovoljio potrebe društva u cjelini i koji bi ostvario vizije suvremenog društva u pogledu odgoja i obrazovanja budućih građana. Takav kurikulum odavna je napustio zastarjeli pristup koji je naglasak stavljao na sadržaj. U suvremenim društvima nacionalni kurikulumi moraju biti usmjereni na razvoj učeničkih kompetencija. Suvremeni, a samim time i interkulturalni kurikulum, mora uvažavati sve izraženija interkulturalna obilježja većine europskih i svjetskih zemalja. Sablić (2011) navodi da vrijednosti i onih koji su drukčiji (u manjini) moraju ući u kurikulum i postati sastavnim dijelom kulture škole. Previšić ističe da:

»... interkulturalni kurikulum treba oblikovati takve programe, sadržaje, nastavna sredstva i metode rada koje neće služiti samo stjecanju znanja, nego i odgoju za suprotstavljanje kulturnim i socijalnim stereotipima, predrasudama, ksenofobiji i stigmatizaciji ljudi.« (Previšić, 1999, 80)

Takav kurikulum bi:

»... trebao predvidjeti uvođenje novih pedagoških pristupa, metoda i praksi na razini škole i razreda, koji pomažu razviti kod učenika (kritički) osjećaj vlastitoga kulturnog identiteta te kroz njega i razumijevanje različitog kulturnog i etničkog identiteta, kako bi mogli otkriti zajedničku ljudskost koja nadilazi sve kulturne i druge razlike.« (Hrvatić i Piršl, 2005, u: Hrvatić, 2012, 157)

Interkulturalni kurikulum postaje nužnom potrebom suvremenih društava koja teže daljnjem razvoju i napretku. U eri globalizacije i medijske ekspanzije interkulturalna kompetencija svakog pojedinca nije samo nadogradnja ili dopuna ostalih kompetencija. Ona postaje preduvjet da se i ostale kompetencije mogu u potpunosti razviti, a pojedinac uspješno raditi i živjeti.

Nastava glazbe je, usudili bismo se tvrditi, idealno područje u kojemu se može razvijati interkulturalna kompetencija učenika. Interkulturalni pristup nastavi glazbe podrazumijeva proučavanje različitih glazbenih kultura, njihovo komparativno promatranje te odnos takve 
glazbe prema kulturama iz kojih i potječu (Anderson, 1991). Zastario pristup nastavi glazbe, koji je usmjeren isključivo ili gotovo isključivo na upoznavanje zapadnoeuropske glazbe, mora što prije ustupiti mjesto suvremenom, interkulturalnom pristupu koji daje važnost i upoznavanju različitih glazbenih tradicija sa svih kontinenata i kultura u cjelini. U izvještaju Međunarodnog udruženja za glazbeni odgoj i obrazovanje (International Society for Music Education - ISME) stoji da bi glazba različitih svjetskih kultura trebala imati značajnu ulogu u području glazbenog obrazovanja (ISME Panel, 1994, u: Beegle, 2012). Proučavajući glazbe svijeta učenici razvijaju glazbenu fleksibilnost koja im omogućuje izvođenje, slušanje i vrednovanje glazbe koja pripada različitim glazbenim stilovima (Dobrota, 2012).

»Krajnji cilj glazbene nastave je proširivanje glazbenog ukusa učenika stoga bi glazbeni pedagog trebao okružiti djecu kvalitetnom i raznolikom glazbom. Među takvim glazbenim iskustvima važno mjesto zasigurno pripada i narodnoj glazbi kraja iz kojega dijete potječe, ali i glazbi iz drugih krajeva svijeta.« (Dobrota i Maslov, 2016)

Fung (1995, u: Abril, 2003) izdvaja tri glavna argumenta za interkulturalni glazbeni odgoj i obrazovanje:

- argument socijalizacije, tj. poučavanje učenika kako bi razvili toleranciju i nepristran stav prema ljudima i glazbi drugih kultura,

- glazbeni argument, koji se odnosi na interkulturalni glazbeni odgoj koji može dovesti do dubljeg razumijevanja glazbe i njenih sastavnica,

- globalni argument, koji drži da interkulturalni glazbeni odgoj i obrazovanje omogućavaju učenicima bolje razumijevanje glazbe, humanosti i kulture kao svjetskih fenomena.

Nastava glazbe u općeobrazovnim školama pruža velike mogućnosti za interkulturalni odgoj jer je glazba sama po sebi interkulturalna. Tri nastavna područja (izvođenje glazbe, skladanje, slušanje) nude brojne mogućnosti za uvažavanje interkulturalizma i različitosti (Ilari, Chen-Hafteck i Crawford, 2013).

Više je razloga za uvođenje interkulturalizma u nastavu glazbe. Prvi je taj da kulturološki sastav učenika u razredu postaje sve raznolikiji. To je prilika da učenici upoznaju glazbu i kulturu svojih kolega, ali je ujedno i prilika da s ponosom upoznaju druge sa svojom kultu- 
rom i tradicijom. Drugi argument polazi od toga da upoznavanje glazbenih tradicija naroda iz drugih krajeva svijeta osnažuje i produbljuje razumijevanje zapadnoeuropske umjetničke glazbe koja se uglavnom i poučava na nastavi glazbe. Treći je razlog globalne prirode i temelji se na pretpostavci da je glazba univerzalni jezik koji nadilazi etničke, nacionalne i geografske podjele (Weidknecht, 2009). Southcott i Joseph (2010) ističu da je nastava glazbe snažan medij za promišljanje kulturalne različitosti. Suvremeni interkulturalni kurikulum je zasigurno polazište za uspješan interkulturalni odgoj učenika. Stoga su u ovom radu analizirani sadržaji kurikuluma za nastavu glazbe u različitim europskim državama s obzirom na implementaciju interkulturalizma.

\section{Metodologija istraživanja}

Analizom sadržaja nacionalnih, predmetnih i školskih kurikuluma, nastavnih planova i programa, sadržaja udžbenika i pripadajućih im CD-a nastojalo se doći do saznanja o implementaciji interkulturalizma u nastavu glazbe različitih europskih država. Također, navedena je satnica osnovnoškolske i gimnazijske nastave za svaku pojedinu državu, interkulturalni sadržaji koji se spominju u dokumentima kao i zastupljenost primjera različitih kultura koji su predviđeni za slušanje, a koji su preduvjet za ostvarenje interkulturalnog odgoja u nastavi glazbe. Analiza je obuhvatila sljedeće države: Hrvatsku, Mađarsku, Sloveniju, Austriju, Njemačku, Češku, Švicarsku, Italiju, Bosnu i Hercegovinu, Francusku, Englesku i Finsku. Ograničili smo se na više razrede osnovne škole i gimnazije. Razlog je taj što tu nastavu glazbe u Republici Hrvatskoj poučavaju predmetni nastavnici glazbe. Takvi nastavnici glazbe poučavaju nastavu glazbe od petog do osmog razreda (u nekim slučajevima i devetog razreda) osnovne škole i u gimnaziji, što je slučaj i u većini europskih država.

\section{Analiza sadržaja}

Hrvatska. U Nacionalnom okvirnom kurikulumu za predškolski odgoj i obrazovanje te opće obvezno i srednjoškolsko obrazovanje (MZOS, 2011) u Republici Hrvatskoj, kao jedan od općih odgojnoobrazovnih ciljeva nastave, navedeno je osposobljavanje učenika za poštivanje različitosti i snošljivosti i za život u današnjem globalizacijskom, interkulturalnom svijetu. Jedno je od načela izrade kurikuluma i 
interkulturalizam, tj. razumijevanje i prihvaćanje kulturoloških razlika s ciljem uklanjanja predrasuda prema pripadnicima drugih kultura. Ujedno, kao jedan od odgojno-obrazovnih ciljeva društveno-humanističkog područja, navodi se da će učenici usvojiti međukulturne kompetencije koje će im omogućiti prihvaćanje i razumijevanje drugoga i drugačijega bez obzira na kulturnu, etničku ili nacionalnu pripadnost. Također, među očekivanim učeničkim postignućima unutar umjetničkog područja navodi se da će učenici slušanjem i izvođenjem djela različitih tradicija razviti toleranciju prema drugim kulturama. Konkretno, u istom dokumentu stoji sljedeće:

»Učenjem pomoću umjetnosti, upoznavanjem i korištenjem različitih izvora podataka, umjetničkih jezika, tehnoloških postupaka, načina izražavanja i komunikacijskih tehnologija, stvaranjem vlastitih umjetničkih ostvaraja, sudjelovanjem u umjetničkim aktivnostima, odgovorom na umjetnička djela i stvaralaštvo te na umjetničke ostvaraje drugih učenika, učenike se osposobljava za istraživanje različitih komunikacijskih putova prema drugim sadržajima, ljudima i kulturama. Odgoj pomoću umjetnosti i za umjetnost bitno pridonosi oblikovanju osobnih te društvenih i kulturnih uvjerenja i svjetonazora, stvaranju osobnoga i društvenoga, nacionalnoga i europskoga kulturnoga identiteta te stjecanju univerzalnih humanističkih vrjednota, poštivanju razlika među ljudima i kulturama, razvijanju empatije, suradnje, solidarnosti te osobne, društvene i kulturne odgovornosti.« (MZOS, 2011, 153)

Jedan je od odgojno-obrazovnih ciljeva umjetničkog područja da učenici usvoje sljedeće:

»... temeljna znanja i pozitivan odnos prema hrvatskoj kulturi i kulturama drugih naroda, prema kulturnoj i prirodnoj baštini te univerzalnim humanističkim vrijednostima.« (MZOS, 2011, 153)

U Nastavnom planu i programu za osnovnu školu među ciljevima odgoja i obrazovanja u osnovnoj školi navodi se:

"Suvremeno društveno-kulturno okruženje pretpostavlja odgoj i obrazovanje odgovorne, istinoljubive, tolerantne i solidarne osobe, osobe stvaralačkoga duha, s dubokim osjećajem za očuvanje nacionalne i kulturne baštine, te poštivanje vrijednosti drugih kultura i naroda. Učenike valja poučiti o i osposobiti za življenje prema načelima poštivanja različitosti i interkulturalnog razumijevanja.« (MZOS, 2006, 10)

Nadalje, u istom dokumentu ističe se da su:

»... odlike osobnosti kojima valja težiti u odgoju i obrazovanju u osnovnoj školi: samostalnost, inicijativnost, istraživački duh, stvaralački interes, komu- 
nikativnost, poštenje, pravednost, samopouzdanje, poštivanje drugoga i briga o drugome, tolerancija i razumijevanje, samostalno i kritičko mišljenje, miroljubivost, odgovornost, osjećaj za jednakovrijednost i jednakopravnost svih ljudi, solidarnost, suradnički duh te samosvjesnost.« (MZOS, 2006, 11)

Međutim, $\mathrm{u}$ istom dokumentu, u okviru predmeta Glazbena kultura, $u$ višim razredima nema navedenog nijednog obveznog primjera izvaneuropske glazbe (osim džeza i roka) koji bi bio predviđen za slušanje ili pjevanje. Također, među obrazovnim postignućima nigdje se ne spominje interkulturalizam ili interkulturalni odgoj. Ipak, u spomenutom dokumentu naglašava se da je:

»... program nastave glazbene kulture otvoren, što znači da daje slobodu učitelju da, uz obvezatne sadržaje, sam uobličuje dobar dio nastave, uzimajući u obzir i želje i mogućnosti učenika. Obvezni dio nastavnoga sadržaja mora biti slušanje i upoznavanje svih pojavnih oblika glazbe: od tzv. umjetničke glazbe, preko narodne (domaće i strane), do jazza i popularnih žanrova svih vrsta. Učitelj je slobodan u izboru načina aktivnoga muziciranja - po načelu realne ostvarivosti i mogućnostima glazbeno relevantnoga dosega." (MZOS, 2006, 84)

Od petog do sedmog razreda predviđeno je upoznavanje samo hrvatske folklorne glazbe. No, neki autori udžbenika za nastavu glazbe u osnovnoj školi ipak su predvidjeli veći broj pjesama različitih kultura koje bi učenici trebali naučiti pjevati. Tako su za peti razred predviđene pjesme iz Švicarske, Slovenije, Njemačke, Engleske, Španjolske, Poljske, Rusije, Italije, Češke, Južnoafričke Republike, Francuske, Grčke i Kube (Ščedrov i Marić, 2007a). U šestom razredu (Marić i Sikirica, 2007) pjevaju se pjesme iz Izraela, Sardinije, Rusije, Mađarske i Engleske. Pjesme iz Engleske, Italije, Francuske, Afrike, Japana i Izraela predviđene su za pjevanje u sedmom razredu (Ščedrov i Marić, 2007b), a u osmom razredu iz Grčke, Amerike, Rusije, Mađarske, Izraela i Koreje (Ščedrov i Marić, 2007c).

U Nastavnom programu Glazbene umjetnosti (MZOS, 1994) ne spominju se interkulturalizam i interkulturalni odgoj, a za slušanje (koje je središnje područje predmeta) nisu predviđeni primjeri izvan zapadnoeuropske glazbene tradicije. Međutim, u predmetnim udžbenicima i na pripadajućim CD-ima nalazi se dvanaest primjera iz glazbene baštine raznih europskih naroda i dvadeset primjera izvaneuropskih kultura sa svih kontinenata. Ipak, spomenuti primjeri uglavnom su vrlo kratkog trajanja i cjelokupna glazba drugih kontinenata trebala bi se upoznati u svega dva do tri školska sata od ukupno 140 sati (Begić, 2016). 
Mađarska. U Republici Mađarskoj nastava glazbe (Ének-zene) obvezna je u prvih deset godina školovanja i zastupljena je $\mathrm{s}$ jednim satom u tjednoj satnici. Drugim riječima, u gimnazijama je obvezna samo prve dvije godine. Školama je ostavljena mogućnost da pri izradi kurikuluma predvide veći broj sati nastave glazbe, no to je slučaj u svega nekoliko gimnazija. Na maturi se učenici mogu odlučiti pisati završni ispit na nižoj ili višoj razini. Nacionalni jezgrovni kurikulum (Hungarian National Core Curriculum) (Ministry of Education and Culture, 2007) osnova je za sastavljanje programa lokalnih škola i on propisuje da glazbeni odgoj i obrazovanje u školi moraju imati važnu ulogu u razvoju djetetova senzibiliteta, intelekta i karaktera. Primarni je cilj glazbenog odgoja i obrazovanja njegovanje ljubavi prema glazbi. U dokumentu se navodi da razumijevajući, cijeneći i reproducirajući glazbu djeca nauče komunicirati pomoću glazbe.

U istom dokumentu navodi se da pri izradi školskih kurikuluma škole moraju voditi računa o napretku u suradnji između temeljnih zajednica (obitelj, nacija, zajednica europskih naroda, čovječanstvo), o ravnopravnosti naroda, nacija, nacionalnih manjina i etničkih i rodnih skupina, kao i o solidarnosti i toleranciji. Također se među obrazovnim ciljevima naglašava da učenici trebaju razvijati osobnu, međuljudsku, interkulturalnu, društvenu i građansku kompetenciju što su preduvjeti za skladan život i integraciju zajednice, predanost i djelovanje za opće dobro. U okviru stjecanja interkulturalne kompetencije učenici bi morali postati svjesni interkulturalnih i društveno-ekonomskih dimenzija europskih društava i razumjeti interakciju između nacionalnog kulturnog identiteta i europskog identiteta. U okviru istog područja učenici bi trebali razumjeti potrebu za očuvanjem kulturne i jezične raznolikosti Europe.

Nacionalni kurikulum izričito navodi dva nastavna područja:

- glazbeno stvaralaštvo

- uvažavanje i vrednovanje glazbe.

Glazbeno stvaralaštvo služi razvoju sposobnosti tumačenja glazbe pomoću pjevanja, a skladbe koje su predviđene u početku mađarske su narodne pjesme, da bi se kasnije repertoar širio i na pjesme drugih kultura i na umjetničku glazbu. Druga je sastavnica ovoga područja improvizacija pomoću koje se djeca uče kreativno izražavati (nerijetko i u kombinaciji s plesom i dramom). Za područje uvažavanja i vrednovanja glazbe slušanje glazbe najvažnija je aktivnost. Učenici se upoznaju sa 
zvukovima instrumenata, poviješću glazbe, najpoznatijim skladateljima i sl. Naglašava se da je slušanje glazbe sinonim za razmišljanje o glazbi i da podrazumijeva usporedbu, apstraktno mišljenje i analizu.

Ipak, u višim razredima osnovne škole prevladavaju isključivo pjesme mađarske narodne tradicije i zapadnoeuropske glazbene kulture. Jedina je iznimka sedmi razred, gdje je predviđeno upoznavanje desetak skladbi drugih kultura (Švicarska, Srbija, Češka, Nizozemska, Španjolska, Ukrajina, Finska i Francuska).

Jedan od obrazovnih ciljeva iz područja nastave glazbe navedenih u gimnazijskom kurikulumu (Müvészetek-ének-zene helyi tanterv) je i upoznavanje različitih kultura i tradicija (Évfolyam Batthyány Lajos Gimnázium, 2013). Nastavna područja koja su obuhvaćena su:

- pjevanje,

- slušanje,

- teorija glazbe,

- razvijanje kompetencija,

- kreativno izražavanje.

Najveći broj sati predviđen je za pjevanje i slušanje glazbe (Lovassy-László-Gymnasium, 2013). Ipak, među predloženim skladbama (Lukin i Ugrin, 2009) ne mogu se pronaći djela koja bi pripadala izvaneuropskim glazbenim kulturama (iznimka su Gershwinova opera Porgy and Bess i Bernsteinov mjuzikl West side story) pa čak ni različitim europskim narodnim tradicijama. Glazbeni repertoar obuhvaća najvećim dijelom mađarsku tradicijsku glazbu, ali i zapadnoeuropsku umjetničku glazbu kojoj, istina, pripadaju i skladatelji iz različitih dijelova kontinenta koji su obogatili europski glazbeni izričaj unošenjem elemenata glazbene tradicije vlastitog naroda u svoje skladbe. No, u cjelini gledano, zastupljen je samo manji broj država, odnosno naroda (Begić, 2016).

Slovenija. U Sloveniji tjedna satnica nastave glazbe u četiri viša razreda osnovne škole iznosi jedan sat (u zadnja tri razreda moguće je izabrati po još jedan sat kao izbornu aktivnost). Osnovne glazbene aktivnosti u osnovnoškolskoj nastavi glazbe su:

- izvođenje glazbe,

- glazbeno stvaralaštvo,

- slušanje glazbe. 
Postignuća u ova tri osnovna područja glazbenog odgoja i obrazovanja prikazana su učenjem i razumijevanjem odabranih glazbenih struktura i razvojem glazbenih sposobnosti, vještina i znanja. Obvezan dio kulturnog života svake osnovne škole školski je pjevački zbor. U privatnim osnovnim školama predviđeno je šest sati tjedno za rad jednoglasnih, dvoglasnih i troglasnih zborova.

Glazbeni odgoj i obrazovanje u osnovnoj školi pružaju učenicima temeljna iskustva potrebna za kritički i aktivan pristup glazbi putem medija i glazbenih događanja, za pjevanje u zboru i druge glazbene aktivnosti te za daljnje obrazovanje koje potiče dublji interes za glazbu. Glazbeni život u školi mora biti u skladu s kulturnim ozračjem. Svojom otvorenošću i glazbenim jezikom glazbeni odgoj i obrazovanje omogućavaju drugačiju, opušteniju komunikaciju u radu škole. Priroda glazbenog obrazovanja omogućuje afektivni, psihomotorni, kognitivni, estetski i psihosocijalni razvoj. Dakle, glavne glazbene aktivnosti (izvođenje, stvaranje i slušanje) izravno su povezane s razvijanjem učenikovih glazbenih sposobnosti. Priroda same glazbe zahtijeva korištenje aktivnih i različitih metoda i oblika rada.

U očekivanim obrazovnim ishodima predviđenima za četiri posljednja razreda osnovne škole navodi se, između ostalog, da bi učenici trebali pjevati određeni repertoar slovenskih i stranih tradicijskih i autorskih pjesama. Međutim, u slovenskom nacionalnom kurikulumu, $\mathrm{u}$ dijelu koji se odnosi na nastavu glazbe u višim razredima osnovne škole, ne navodi se interkulturalizam kao jedna od sastavnica niti se među slušnim primjerima nalaze skladbe koje bi pripadale narodima drugih kultura. Isključivo su navedene skladbe slovenskih i europskih skladatelja i skladbe koje pripadaju zapadnoeuropskoj umjetničkoj glazbi (Ministrstvo za izobraževanje, znanost in šport, 2004).

Nastava glazbe pod nazivom Glasba obvezna je samo u prvom razredu gimnazije s ukupno 70 sati (52 kao obvezan predmet i 18 kao izborni). U drugom, trećem i četvrtom razredu predmet ima status izbornog predmeta i moguće je odabrati jedan od triju različitih modula: Glazbeni jezik, Svjetska glazbena kultura i Slovenska glazbena kultura. Sva tri modula (svaki po 70 sati) međusobno se povezuju i nadopunjavaju (Ministrstvo za izobraževanje, znanost in šport, 1999). Osim toga, svaka gimnazija mora imati pjevački zbor čija satnica može biti i do četiri sata tjedno (meNet. Music Education in Slovenia). 
U nastavnom planu za gimnazije (Ministrstvo za izobraževanje, znanost in šport, 2010) među obrazovnim ciljevima nastave glazbe, između ostalog, navodi se:

- oblikovanje pozitivnog odnosa i odgovornosti prema slovenskoj i svjetskoj glazbi,

- razvijanje osjetljivosti i tolerancije prema različitim glazbenim kulturama,

- oblikovanje glazbenih vrednota koje su važne za slovensku i svjetsku glazbenu kulturu.

Nastavna područja koja su obuhvaćena nastavom glazbe su sljedeća:

- slušanje glazbe,

- pjevanje i sviranje,

- glazbeno stvaralaštvo,

- glazbeni jezik.

Interkulturalizam se navodi kao jedno od obilježja nastave, ali samo kod upoznavanja glazbe 20. i 21. stoljeća. U glazbenim primjerima predviđenima za državnu maturu (Državni izpitni center, 2014) nalaze se isključivo djela zapadnoeuropske umjetničke glazbe, slovenske glazbe i džeza. Dakle, nema slušnih zapisa koji pripadaju izvaneuropskim glazbenim kulturama (Begić, 2016).

Austrija. Nastava glazbe u Republici Austriji pod nazivom Musikerziehung u posljednjim četirima razredima osnovne škole ima sljedeću tjednu satnicu: u petom i šestom razredu po dva sata tjedno, a u sedmom i osmom po jedan sat. U kurikulumu se navode vrlo opći ciljevi učenja i poučavanja u nastavi glazbe koji su podijeljeni u šest jednako važnih skupina:

- vokalno glazbeno stvaralaštvo,

- instrumentalno glazbeno stvaralaštvo,

- slušanje,

- kretanje na glazbu,

- kreativnost,

- glazbena teorija. 
Tri su ključna kurikulumska područja koja se odnose na nastavu glazbe. To su praktično muziciranje, muzikologija i slušanje glazbe. U okviru posljednjeg područja navodi se da kod učenika treba pobuditi znatiželju spram novih i drugačijih vrsta glazbe. Ističe se da su sva tri područja usko povezana i da ih se po potrebi može dodatno integrirati $i$ to naročito $s$ interkulturalnog stajališta. Kao najvažniji interkulturalni aspekt spominje se da susreti s oblicima izražavanja drugih kultura trebaju poticati poštovanje i kritičko razumijevanje.

Nastava glazbe obvezna je u prva dva razreda gimnazije, dok u trećem i četvrtom razredu učenici moraju izabrati između predmeta Glazba i Umjetnost. Osim toga, tijekom sve četiri godine učenici se mogu odlučiti i za izborne predmete poput Zborskog pjevanja, Skupnog muziciranja i slično. Tjedna satnica nastave glazbe ponešto se razlikuje u različitim vrstama gimnazija i kreće se od dva sata u prva dva razreda do dva sata u prva tri i jednog u četvrtom razredu (Bundesministerin für Bildung, Wissenschaft und Kultur, 2003).

U nastavnom planu za nastavu glazbe u gimnaziji navodi se da nastava glazbe:

- treba promicati toleranciju prema novom i drugačijem,

- treba služiti kao sredstvo kulturne komunikacije.

Nastavna područja pokrivena nastavom glazbe su:

- glazbeno izražavanje (vokalno, instrumentalno, pokretom...),

- teorija i povijest glazbe,

- slušanje glazbe.

Za slušanje su predviđeni brojni primjeri iz različitih stilskih razdoblja i među njima prevladavaju skladbe zapadnoeuropske umjetničke glazbe. Ipak, predviđeni su i glazbeni primjeri drugih kultura poput indijske, kineske, tibetanske, jamajčanske i bugarske (Spielpläne Oberstufe, 2016, u: Begić, 2016).

Njemačka. Savezna Republika Njemačka nema nacionalni nastavni plan i program, već svaka od šesnaest saveznih pokrajina ima svoj vlastiti. Prema mišljenju glazbenih stručnjaka, glavni su cilj nastave glazbe učenikove aktivnosti poput pjevanja i individualnog i skupnog muziciranja. Osnovna su nastavna područja:

- muziciranje,

- muzikologija, 
- prezentacija glazbe,

- slušanje glazbe,

- znanje o glazbi,

- glazbena refleksija.

U Nastavnom planu i programu za nastavu glazbe u saveznoj pokrajini Bavarskoj kao aktivnosti navode se i plesanje plesova koji potječu od različitih kultura i različitih zemalja i pjevanje pjesama drugih naroda. Posebno je zanimljivo da se spominje upoznavanje pjesama $\mathrm{i}$ plesova kultura kojima pripadaju učenici koji nisu dio većinske kulture u Bavarskoj. Također se navodi mogućnost upoznavanja s instrumentima drugih kultura kojima ti učenici pripadaju.

Nadalje, predviđeno je upoznavanje neeuropskih glazbenih kultura (npr. afričke, južnoameričke, indijske...), ritamskih instrumenata, različitih bubnjeva, osnovnih tehnika sviranja na bongosima, a svakako, ako je moguće, predlaže se uživo poslušati muziciranje glazbenika koji izvode neeuropsku glazbu (Staatsministerin für Unterricht und Kultus, 2004).

Nastavna područja koja su obuhvaćena u gimnazijskoj nastavi glazbe su:

- uočavanje i razumijevanje glazbe,

- glazbeno izražavanje,

- razmišljanje o glazbi.

Okvirni nastavni plan za nastavu glazbe savezne pokrajine Berlin (Senatsverwaltung für Bildung, Jugend und Sport, 2006) navodi kao dio sadržaja i očekivanog razvoja kompetencija i upoznavanje i razumijevanje glazbe različitih kultura. Učenici bi trebali plesanjem, pjevanjem, slušanjem i izvođenjem skladba različitih naroda upoznati raznolikost $\mathrm{i}$ bogatstvo glazbenog izričaja i razviti osjetljivost prema različitim kulturama u njemačkom društvu. Iako i ovdje dominiraju skladbe zapadnoeuropske umjetničke glazbe, određeni broj primjera potječe iz američke glazbene tradicije (kantri, rep...), a u školskom kurikulumu gimnazije iz Lohmara (Gymnasiums Lohmar, 2017) predviđa se u trećem razredu i upoznavanje turske, kubanske, južnoafričke i zapadnoafričke glazbe (Begić, 2016).

Češka. Nastavna područja koja su zastupljena u nastavi glazbe u višim razredima osnovne škole u Republici Češkoj su: 
- vokalne aktivnosti,

- instrumentalne aktivnosti,

- pokret uz glazbu,

- aktivnost slušanja.

Nažalost, ne spominje se upoznavanje glazba drugih kultura niti su predviđeni slušni primjeri izvaneuropskih glazbenih tradicija (Research Institute of Education in Prague, 2007).

Područja koja su obuhvaćena gimnazijskom nastavom glazbe su:

- pjevanje,

- izvođenje glazbe,

- kretanje uz glazbu,

- slušanje glazbe.

Interkulturalni pristup ne navodi se izričito u očekivanim ishodima samoga predmeta, već je predviđen kao jedna od kroskurikularnih tema koje se protežu kroz sva četiri razreda i među kojima su i Individualni $i$ društveni odgoj i obrazovanje, Odgoj i obrazovanje u europskom i globalnom kontekstu itd. (Institute for Information on Education, 2009). U sadržaju nastave glazbe (Hudebni výchova) nije predviđeno upoznavanje glazba naroda drugih kontinenata osim skladba skladatelja klasične glazbe koji su bili nadahnuti izvaneuropskom glazbenom tradicijom (Śkolni vzdělávaci program pro čtyřleté gymnázium a vyšši stupen̆ osmiletého gymnázia, 2012, u: Begić, 2016).

Slovačka. Nastava glazbe obvezan je predmet i u prva tri viša razreda osnovne škole u Slovačkoj (peti, šesti i sedmi) i zastupljena je s jednim satom u tjednoj satnici. Nakon toga predmet mijenja naziv u Umjetnički odgoj i obrazovanje i satnica mu se smanjuje na samo pola sata. Isto tako, u posljednja dva razreda nastavu organizira nastavnik umjetnosti, a ne glazbe.

Nastavna područja od petog do devetog razreda zastupljena u nastavi glazbe su:

- pjevanje,

- sviranje instrumenta,

- opažanje,

- glazba i pokret,

- glazba i drama. 
Od interkulturalnih sadržaja, samo u devetom razredu predviđena je nastavna cjelina pod nazivom Svjetska i etnička glazba.

U gimnaziji se nastava glazbe ne odvija kao samostalan predmet, već samo djelomično tijekom četiri godine (jedan sat tjedno) u okviru predmeta pod nazivom Umjetnost i kultura (Umenie a kultúra). U nastavnim planovima nije precizirano koliki će se dio sadržaja predmeta odvijati isključivo glazbom. Naime, glazba se uglavnom javlja u sintezi s drugim umjetnostima (dramom, plesom, filmom...). Pozitivna je činjenica da se izričito navodi razvijanje učenikove interkulturalne kompetencije za komunikaciju i suradnju s pripadnicima drugih kultura (Begić, 2016).

Švicarska. Švicarski kurikulum za nastavu glazbe navodi sljedeća nastavna područja:

- pjevanje i govor,

- slušanje i orijentacija,

- pokret i ples,

- glazbeno stvaralaštvo,

- proces kreativnosti,

- primjena glazbenog znanja.

Među očekivanim kompetencijama koje bi učenici trebali steći navodi se, ukratko, da će učenici moći prepoznati glazbu različitih razdoblja, žanrova i kultura s uvažavanjem tolerancije spram drugačijega.

Nastava glazbe u gimnaziji zastupljena je s dva sata tjedno u prva dva razreda i u prvom polugodištu trećeg razreda. Osim toga, učenici su u mogućnosti u gimnazijama upisati različite smjerove u kojima su određena područja zastupljena većom satnicom. Takav je slučaj i s glazbenim smjerom, gdje je satnica nastave glazbe veća, traje sve četiri godine i još su dodani predmeti poput Sviranja i Pjevanja u zboru. Nastavom glazbe (Musik) obuhvaćena su sljedeća područja:

- praktično muziciranje,

- glazbena znanja i vještine,

- susret s glazbom - doživljaj glazbe.

I ovdje (Erziehungsdirektion des Kantons Bern, 2017) je zamjetna dominacija zapadnoeuropske glazbe, no u sadržaju predmeta naglašava 
se potreba za upoznavanjem glazba različitih kultura (i onih koje su geografski udaljene) i nužnost stjecanja interkulturalne kompetencije (Begić, 2016).

Italija. Očekivani ishodi nastave glazbe u Italiji navedeni u kurikulumu za osnovnu školu govore da će učenici na kraju obrazovnog ciklusa moći aktivno sudjelovati u realizaciji glazbenih događanja izvodeći i tumačeći vokalne i instrumentalne skladbe različitih stilova i kultura. Iako se ovdje ne navodi razvijanje interkulturalne kompetencije među obrazovnim ciljevima, između ostalog se ističe da učenici trebaju povezati vlastita iskustva s drugim kulturama, naglašavajući interkulturalnu dimenziju.

Nastava glazbe (Educazione musicale) nije predviđena u gimnazijskom obrazovanju, već se odvija samo u srednjim glazbenim školama (Liceo musicale) (meNet. Music Education in Italy).

Bosna i Hercegovina. Nastavna područja iz predmeta Muzička/ Glazbena kultura koja se navode u Okvirnom nastavnom planu i programu za devetogodišnju osnovnu školu u Federaciji Bosne i Hercegovine su:

- pjevanje i sviranje,

- muzičke/glazbene igre,

- brojalice,

- slušanje muzike,

- dječje stvaralaštvo.

U nastavnom planu za peti razred navodi se da je on interkulturalnog karaktera jer je predviđeno upoznavanje s glazbom Hrvatske, Srbije, Slovenije, Slovačke, Engleske, Škotske, Francuske, Austrije, Njemačke, Rusije, Norveške i Meksika. U šestom razredu predviđeno je učenje glazbenih igara naroda drugih kultura (Brazil, Izrael, Libija, Italija). Za sedmi razred također su navedene skladbe koje pripadaju različitim tradicijama europskih i izvaneuropskih naroda (Hrvatska, Srbija, Poljska, Belgija, Rusija, Izrael). U osmom razredu navode se skladbe iz Japana, Italije, SAD, Grčke, Rumunjske i Danske. Za deveti razred predviđene su, između ostalih, pjesme iz Makedonije, Rusije i Brazila (Federalno ministarstvo obrazovanja i nauke, 2004).

Satnica nastave glazbe u gimnazijama razlikuje se po kantonima, pa tako, primjerice, u gimnazijama sarajevskog kantona predmet je ob- 
vezan samo u drugom razredu (dva sata tjedno), a u kantonu Središnja Bosna predmet je obvezan u sve četiri godine školovanja (jedan sat tjedno) (Ministarstvo obrazovanja, znanosti, kulture i športa, 2013). Interkulturalnih sadržaja gotovo da nema jer se nastava svodi na povijesni prikaz razvoja glazbe s isključivim naglaskom na razvoj zapadnoeuropske umjetničke glazbe.

Francuska. Francuski obrazovni sustav vrlo je centraliziran, organiziran i razgranat. U osnovnim i srednjim školama nastavni plan i program isti je za sve učenike. Međutim, postoje specijalizirani moduli i razne mogućnosti koje učenici mogu izabrati. U višim razredima osnovne škole nastava glazbe obvezan je predmet i zastupljena je u tjednoj satnici s jednim satom. Povrh toga, učenici mogu izabrati pjevanje u zboru ili učenje sviranja instrumenta kao slobodnu aktivnost. Temeljna nastavna područja su:

- glazbena aktivnost (naročito pjevanje)

- slušanje glazbe.

Između ostalog, jedan je od nastavnih sadržaja upoznavanje različitih glazbenih stilova, gdje se navodi da bi trebalo upoznati i glazbu drugih kontinenata (Afrike, Južne Amerike i Azije) (Ministère de l'Éducation nationale, 2008). U ostalim nastavnim područjima nisu zamjetni elementi interkulturalizma u značajnijoj mjeri.

U gimnazijama (lycée) glazba je izborni predmet i učenici mogu birati između većeg broja različitih modula. Ako se odluče za Glazbu različitih kultura, nudi im se mogućnost upoznavanja glazbe svih kontinenata (Ministère de l'Éducation nationale, 2010).

Ujedinjeno Kraljevstvo. U engleskom nacionalnom kurikulumu navodi se da je glazba snažan, jedinstven oblik komunikacije koji može promijeniti način na koji učenici osjećaju, misle i djeluju. Ona zaokuplja um i osjećaj i omogućuje osobni izraz, razmišljanje i emocionalni razvoj. Kao sastavni dio kulture, prošlosti i sadašnjosti, ona pomaže učenicima razumjeti odnose prema drugima, izgraditi snažne veze između doma, škole i šireg svijeta. Nastava glazbe razvija sposobnost učenika da sluša i cijeni različite vrste glazba i kritički sudi o njihovoj kvaliteti. Nastava glazbe potiče aktivno sudjelovanje u različitim oblicima amaterskog muziciranja, pojedinačnim i skupnim, kao i razvitak osjećaja grupnog identiteta i zajedništva. To također povećava samodis- 
ciplinu i kreativnost i estetski senzibilitet (meNet. Music Education in the United Kingdom).

U višim razredima osnovne škole (Key stage 2 i Key stage 3) nastava glazbe je obvezna, ali se školama prepušta da odluče o satnici predmeta. U posljednja tri razreda učenici bi trebali upoznati glazbu različitih kultura (Department for Education, 2013), a također se navodi da glazbeni sadržaji trebaju odražavati raznolik kulturni krajolik Engleske. Tri su najvažnija nastavna područja:

- skladanje,

- izvođenje,

- slušanje.

U srednjoškolskom obrazovanju glazba nije samostalan predmet, već se poučava u okviru Umjetnosti (Arts), a nastavni sadržaji uglavnom su prepušteni na izbor školama.

Finska. Finski nacionalni kurikulum vrlo je fleksibilan. Obrazovni ciljevi koji su u njemu navedeni ističu razvijanje učenikovih pozitivnih stavova, razumijevanje slušanja glazbe i interakciju pomoću glazbe. Jedna je od središnjih kroskurikularnih tema i u osnovnoj i u srednjoj školi obrazovanje za međunarodno razumijevanje.

Što se tiče plana i programa nastave glazbe, ključna je riječ raznovrsnost. Dugo se vremena nastava glazbe obično nazivala nastavom pjevanja, međutim u novije vrijeme sve veća pozornost pridaje se instrumentalnoj glazbi, slušanju glazbe i različitim oblicima kreativnog rada. Broj tjednih sati ovisi o školi. Minimalna je satnica predmeta od prvog do šestog razreda jedan sat tjedno. U prvom razredu niže srednje škole učenici također imaju jedan sat tjedno obvezne nastave glazbe, a u drugom i trećem razredu ona postaje izborni predmet.

Osim srednjih glazbenih škola, ostale srednje škole, kao i gimnazije, mogu imati nastavni plan i program s naglaskom na glazbi. Prema nacionalnom kurikulumu, u takvim školama moguće je imati i do pet predmeta koji su vezani uz glazbu. U prvom i drugom razredu gimnazije svi učenici moraju pohađati nastavu glazbe u ukupnom trajanju od 38 sati, a nakon toga mogu, ali i ne moraju odabrati taj predmet. U kurikulumu i za osnovno i za gimnazijsko obrazovanje navodi se da će učenici, između ostalog, upoznati glazbu različitih stilova i kultura. 


\section{Interpretacija rezultata}

U nastavku rada tablično je prikazana satnica nastave glazbe $u$ osnovnim školama i gimnazijama. Također, tablično je prikazana i zastupljenost interkulturalnih sadržaja u nastavi glazbe.

Tablica 1. Zastupljenost nastave glazbe u tjednoj satnici viših razreda osnovne škole

\begin{tabular}{|l|c|c|c|c|c|}
\hline \multirow{2}{*}{ Država } & \multicolumn{5}{|c|}{$\begin{array}{c}\text { Zastupljenost nastave glazbe u tjednoj satnici } \\
\text { viših razreda osnovne škole }\end{array}$} \\
\cline { 2 - 6 } & 5. raz. & 6. raz. & 7. raz. & 8. raz. & 9. raz. \\
\hline Hrvatska & 1 & 1 & 1 & 1 & - \\
\hline Mađarska & 1 & 1 & 1 & 1 & - \\
\hline Slovenija & 1 & 1 & 1 & 1 & 1 \\
\hline Austrija & 2 & 2 & 1 & 1 & - \\
\hline Njemačka & 2 & 2 & 1 & 1 & - \\
\hline Češka & 1 & 1 & 1 & 1 & - \\
\hline Slovačka & 1 & 1 & 1 & $1 / 2^{1}$ & $1 / 2^{1}$ \\
\hline Švicarska & 3 & 3 & 3 & $1-2^{2}$ & $1-2^{2}$ \\
\hline Italija & 2 & 2 & 2 & 2 & - \\
\hline BiH & 1 & 1 & 1 & 1 & 1 \\
\hline Francuska & 1 & 1 & - & - & - \\
\hline Engleska & $*$ & $*$ & - & - & - \\
\hline Finska & 1 & 1 & - & - & - \\
\hline
\end{tabular}

1 - nije samostalan predmet

2 - učenici se opredjeljuju za nastavu glazbe ili umjetnosti

* - satnica predmeta ovisi o školi

Kao što je vidljivo iz Tablice 1, nastava glazbe tijekom osnovnoškolskog obrazovanja u navedenim državama obvezan je predmet bez obzira je li riječ o osnovnoj školi koja traje šest, osam ili devet godina. U velikoj većini obrazovnih sustava nastava glazbe samostalan je predmet $i$ tjedna satnica predmeta varira od jedan (u većini zemalja) do tri (u Švicarskoj), a u nekima je satnica u potpunosti prepuštena odluci same škole (Engleska). Bez obzira na satnicu, iz podataka se može zaključiti da je osnovnoškolska nastava glazbe u europskim državama tretirana kao važan obvezni predmet. Osim toga, školama je gotovo uvijek omo- 
gućeno da ponude učenicima dodatne sadržaje i izvannastavne aktivnosti poput pjevačkog zbora, sviranja u orkestru, individualnog sviranja, glazbe na računalu i slično.

Tablica 2. Zastupljenost nastave glazbe u tjednoj satnici gimnazije

\begin{tabular}{|l|c|c|c|c|}
\hline \multirow{2}{*}{ Država } & \multicolumn{5}{c|}{$\begin{array}{c}\text { Zastupljenost nastave glazbe u tjednoj } \\
\text { satnici gimnazije }\end{array}$} \\
\cline { 2 - 5 } & 1. raz. & 2. raz. & 3. raz. & 4. raz. \\
\hline Hrvatska & 1 & 1 & 1 & 1 \\
\hline Mađarska & 1 & 1 & $1^{1}$ & $1^{1}$ \\
\hline Slovenija & $2^{2}$ & $2^{1}$ & $2^{1}$ & $2^{1}$ \\
\hline Austrija & 2 & 2 & $2^{1}$ & $1^{1}$ \\
\hline Njemačka & 1 & 1 & $2^{3}$ & $2^{3}$ \\
\hline Češka & $2^{3}$ & $2^{3}$ & $2^{1}$ & $2^{1}$ \\
\hline Slovačka & $1^{4}$ & $1^{4}$ & $1^{4}$ & $1^{4}$ \\
\hline Švicarska & 2 & 2 & $1 / 2$ & - \\
\hline Italija & - & - & - & - \\
\hline BiH & 1 & 1 & 1 & 1 \\
\hline Francuska & $1^{1}$ & $1^{1}$ & $1^{1}$ & $1^{1}$ \\
\hline Engleska & $1^{4}$ & $1^{4}$ & $1^{4}$ & $1^{4}$ \\
\hline Finska & $1 / 2$ & $1 / 2$ & $1^{1}$ & $1^{1}$ \\
\hline
\end{tabular}

1 - kao izborni predmet

2 - kombinacija redovnog i izbornog

3 - učenici se opredjeljuju za nastavu glazbe ili umjetnosti

4 - nije samostalan predmet

U većini navedenih država nastava glazbe obvezan je predmet u gimnazijama, dok je otprilike u polovici samostalan predmet. Samo u Italiji nastava glazbe nije zastupljena u gimnazijskom programu. Tjedna satnica predmeta u rasponu je od jednog do dva sata (Tablica 2). Može se zamijetiti da, nadovezujući se također i na osnovnu školu, Švicarska malo prednjači u ukupnom broju sati nastave glazbe. 
Tablica 3. Zastupljenost interkulturalnih sadržaja u nacionalnom kurikulumu i/ili nastavnom programu za nastavu glazbe u osnovnoj školi

\begin{tabular}{|l|c|}
\hline \multicolumn{1}{|c|}{ Država } & $\begin{array}{c}\text { Zastupljenost interkulturalnih sadržaja u } \\
\text { nacionalnom kurikulumu i/ili nastavnom } \\
\text { programu za nastavu glazbe u osnovnoj školi }\end{array}$ \\
\hline Hrvatska & + \\
\hline Mađarska & + \\
\hline Slovenija & + \\
\hline Austrija & + \\
\hline Njemačka & + \\
\hline Češka & - \\
\hline Slovačka & + \\
\hline Švicarska & + \\
\hline Italija & + \\
\hline BiH & + \\
\hline Francuska & + \\
\hline Engleska & + \\
\hline Finska & + \\
\hline
\end{tabular}

Interkulturalni nastavni sadržaji implementirani u kurikulume ili nastavne programe pronađeni su u većini država (Tablica 3). U nekima se o njima govori kao kroskurikularnim temama, a u nekima se izričito navode među obrazovnim ciljevima ili ishodima učenja u nastavi glazbe. Ova pozitivna činjenica ohrabruje, no pitanje je koliko je ideja interkulturalizma doista i zaživjela u praksi nastave glazbe.

Tablica 4. Zastupljenost interkulturalnih sadržaja u nacionalnom kurikulumu i/ili nastavnom programu za nastavu glazbe u gimnaziji

\begin{tabular}{|l|c|}
\hline \multicolumn{1}{|c|}{ Država } & $\begin{array}{c}\text { Zastupljenost interkulturalnih sadržaja u } \\
\text { nacionalnom kurikulumu i/ili nastavnom } \\
\text { programu za nastavu glazbe u gimnaziji }\end{array}$ \\
\hline Hrvatska & - \\
\hline Mađarska & + \\
\hline Slovenija & + \\
\hline Austrija & + \\
\hline
\end{tabular}




\begin{tabular}{|l|c|}
\hline \multicolumn{1}{|c|}{ Država } & $\begin{array}{c}\text { Zastupljenost interkulturalnih sadržaja u } \\
\text { nacionalnom kurikulumu i/ili nastavnom } \\
\text { programu za nastavu glazbe u gimnaziji }\end{array}$ \\
\hline Njemačka & + \\
\hline Češka & - \\
\hline Slovačka & + \\
\hline Švicarska & + \\
\hline Italija & - \\
\hline BiH & - \\
\hline Francuska & + \\
\hline Engleska & - \\
\hline Finska & + \\
\hline
\end{tabular}

Nažalost, podatci o implementaciji interkulturalizma u kurikulume i nastavne programe gimnazijske nastave glazbe europskih država (Tablica 4) ukazuju na manju prisutnost interkulturalnih sadržaja u odnosu na osnovne škole. Naime, u nekim državama (npr. Hrvatska, Bosna i Hercegovina) cjelokupna nastava glazbe u gimnazijama orijentirana je na povijesni prikaz razvoja glazbe (što samo po sebi i ne mora biti tako loše), ali samo iz perspektive zapadnoeuropske umjetničke glazbe.

\section{Zaključak}

Može se zaključiti da su nastavni sadržaji, koji su orijentirani na izvaneuropsku glazbu, nedovoljno prisutni u nastavi glazbe. Unatoč svim naporima, glazba zapadnoumjetničke tradicije ostala je dominantno područje u školama (Asmus, 2001; College Music Society Study Group on the Content of the Undergraduate Music Curriculum, 1986; Emmons, 2004; Humphreys, 2002, 2006; Klocko, 1989; Nettle, 1995; Norman, 1999; Reimer, 2002; Rideout, 1990; Volk, 1998; Wicks, 1998, u: Wang i Humphreys, 2009). Gimnazijska nastava glazbe mora biti koncipirana upravo u suprotnom smjeru. Naime, glazba je područje koje je prožeto duhom interkulturalizma možda više nego bilo koje drugo. Jer, kako ističe Dobrota (2009), superiornost zapadne umjetničke glazbe u najmanju je ruku diskutabilna i vrlo je upitno tvrditi da je takva glazba prirodnija i izražajnija spram ostalih vrsta glazba. Mišljenja smo 
da je napredak u kreiranju nastavnih sadržaja, s obzirom na interkulturalni odgoj u nastavi glazbe, moguć jedino uvođenjem i upoznavanjem glazbe izvaneuropskih glazbenih tradicija i kultura. Ne treba posebno naglašavati da nam današnja tehnologija omogućava da s učenicima »putujemo« i u najudaljenije dijelove svijeta.

Implementacija interkulturalnih sadržaja u školske kurikulume nije sama po sebi dovoljna. Obrazovni ciljevi i ishodi učenja nisu ostvarivi bez potpunog angažmana interkulturalno kompetentnog nastavnika. Školskim kurikulumom ponekad se nastoje smanjiti kulturne raznolikosti, ali nastavnici su sve više svjesni da oni moraju znati mnogo više o kulturi iz koje potječu svi učenici, kao i o zajednicama u kojima učenici žive. Nastavnici shvaćaju da učenici dolaze iz različitih kulturnih sredina i imaju različite potrebe. Nažalost, svi nastavnici nemaju potrebne vještine koje bi zadovoljile potrebe učenika, ali i oni moraju biti spremni poučavati svu djecu (Gorham, 2001).

Suvremeni kurikulum mora uvažavati kulturne razlike u svakom pojedinom razredu, svakoj školi, naselju, gradu, državi. Ako nije koncipiran na ovim temeljima, neće se u potpunosti ostvariti ciljevi koji su predviđeni, ma kako god oni bili postavljeni i dobro osmišljeni. Mišljenja smo da je interkulturalni kurikulum jednostavno suštinska potreba svakog modernog odgojno-obrazovnog sustava.

\section{Literatura}

Abril, R. Carlos (2003), Beyond Content Integration: Multicutural Dimensions in the Application of Music Teaching and Learning, doctoral thesis, Ohio: The Ohio State University. Dostupno na:

https://etd.ohiolink.edu/rws_etd/document/get/osu1054142600/inline [22. 10. 2016.]

Anderson, William M. (1991), Teaching Music with a Multicultural Approach, Reston, VA: Music Educators National Conference.

Beegle, Amy C. (2012), »World Music Resources«, General Music Today, 26(1), str. 48-49. doi: http://dx.doi.org/10.1177/1048371312453723

Begić, Amir (2016), »Intercultural content in grammar school music instruction in Central European countries«, Pannoniana - Journal of Humanities, 1, str. 106-114.

Bradley, Deborah Gail (2007), $\gg$ The sounds of silence: Talking race in music education«, Action, Criticism, and Theory for Music Education, 6(4), str. 132- 
162. Dostupno na: http://act.maydaygroup.org/articles/Bradley6_4.pdf [2. 5 . 2017.]

Bundesministerin für Bildung, Wissenschaft und Kultur (2003), Wochenstundenentlastungs und Rechtsbereinigungsverordnung, Wien: Bundesministerium für Bildung, Wissenschaft und Kultur. Dostupno na: https://www.bmbf.gv.at/ schulen/lehrdr/gesetze_verordnungen/Verordnung_Aenderung_der9110. html [25. 2. 2017.]

Department for Education (2013), The national curriculum in England, Manchester: Department for Education. Dostupno na:

https://www.gov.uk/government/uploads/system/uploads/attachment data/ file/210969/NC_framework_document_-_FINAL.pdf [25. 11. 2016.]

Dobrota, Snježana (2009), »Svjetska glazba u suvremenom glazbenom obrazovanju«, Pedagogijska istraživanja, 6(1-2), str. 153-161.

Dobrota, Snježana (2012), »Povijesni razvoj interkulturalnog glazbenog obrazovanja«, u: Hrvatić, Neven i Klapan, Anita (ur.), Pedagogija i kultura: teorijskometodološka određenja pedagogijske znanosti, Zagreb: Hrvatsko pedagogijsko društvo, str. 133-141.

Dobrota, Snježana i Maslov, Matea (2016), »Glazbene preferencije učenika prema narodnoj glazbi«, Metodički ogledi, 22(1), str. 9-22.

doi: https://doi.org/10.21464/mo41.221.922

Drandić, Dijana (2010), »Tradicijska glazba u kontekstu interkulturalnih kompetencija učitelja«, Pedagogijska istraživanja, 7(1), str. 95-109.

Državni izpitni center (2014), Izbor glasbenih del in video posnetkov za pisni ispit splošne mature iz glasbe 2015, Ljubljana: Državni izpitni center. Dostupno na: http://www.dijaski.net/gradivo/gla_mat_tematski_sklop_2015_01, [16.3. 2017.]

Erziehungsdirektion des Kantons Bern (2017), Lehrplan für den gymnasialen Bildungsgang - Fachlehrplan Musik, Bern: Erziehungsdirektion des Kantons Bern. Dostupno na:

http://www.erz.be.ch/erz/de/index/mittelschule/mittelschule/gymnasium/ lehrplan_maturitaetsausbildung.assetref/dam/documents/ERZ/MBA/de/ AMS/ams_klm_musik.pdf [11.3.2017.]

Évfolyam Batthyány Lajos Gimnázium (2013), Müvészetek - ének-zene helyi tanterv 11-12, Nagykanizsa: Évfolyam Batthyány Lajos Gimnázium. Dostupno na: http://www.blg.hu/tantervek/muveszetek_enek_1_1.pdf [1. 3. 2017.]

Federalno ministarstvo obrazovanja i nauke (2004), Okvirni nastavni plan i program za devetogodišnju osnovnu školu u Federaciji Bosne i Hercegovine, Sarajevo: Federalno ministarstvo obrazovanja i nauke. Dostupno na:

http://www.sobih.ba/siteoo/images/stories/galerije/Zakonska_akta/okvini\%20npp. $\underline{\text { pdf }[16.3 .2017 .] ~}$ 
Gymnasiums Lohmar (2017), Curriculum für das Fach Musik in der Oberstufe des Gymnasiums Lohmar - Sekundarstufe II. Lohmar: Gymnasiums Lohmar. Dostupno na:

http://www.gymnasium-lohmar.org/images/Faecher/Musik/Curriculum_Musik Oberstufe.pdf [6. 11. 2017.]

Gorham, Ephraim (2001), Multicultural Teaching Competence as Perceived by Elementary School Teachers, doctoral thesis, Blacksburg, Virginia: Faculty of the Virginia Polytechnic Institute. Dostupno na: http://scholar.lib.vt.edu/theses/available/etd-03252002-164438/unrestricted/egorham.pdf [10. 9. 2015.]

Hrvatić, Neven (2012), »Pedagogija i kultura«, u: Hrvatić, Neven i Klapan, Anita (ur.), Pedagogija i kultura: teorijsko-metodološka određenja pedagogijske znanosti, Zagreb: Hrvatsko pedagogijsko društvo, str. 151-160.

Ilari, Beatriz, Chen-Hafteck, Lily i Crawford, Lisa (2013), „Singing and cultural understanding: A music education perspective«, International Journal of $\mathrm{Mu}$ sic Education, 31(2), str. 202-216.

doi: http://dx.doi.org/10.1177/0255761413487281

Institute for Information on Education (2009), Structures of Education and Training Systems in Europe - Czech Republic, Praha: Institute for Information on Education. Dostupno na: http://www.msmt.cz/file/27043/download/ [7. 1. 2017.]

Izgarjan, Aleksandra, Markov, Slobodanka i Prodanović-Stankić, Diana (2013), »Gender and politics as the dominant factors in the perceptions of multicultural education. Gender studies«, The Journal of West University, 12(1), str. 333-360. Dostupno na:

http://www.degruyter.com/view/j/genst.2013.12.issue-1/genst-2013-0021/ genst-2013-0021.xml?format=INT [29. 10. 2016.]

Lovassy-László-Gymnasium (2013), Ének-zene helyi tanterv, Veszprém: LovassyLászló-Gymnasium. Dostupno na:

http://www.lovassy.hu/online/egyeb/e-dok/pp2013/Enek_zene.pdf [1. 3. 2017.]

Lukin, László i Ugrin, Gábor (2009), Ének-zene - középiskola 9-10. Évfolyam, Budapest: Nemzeti Tankönyvkiadó Budapest. Dostupno na:

http://www.eladomakonyvem.hu/konyv/enek-zene-kozepiskola-9-10-evfolyam83351 [1. 12. 2016.]

Marić, Saša i Sikirica, Jelena (2007), Glazbena šestica, Zagreb: Profil.

Ministère de l'Éducation nationale (2008), Programmes du collège Programmes de l'enseignement d'éducation musicale, Paris: Ministère de l'Éducation nationale. Dostupno na:

http://cache.media.education.gouv.fr/file/special_6/21/4/programme_musique general_33214.pdf [7.2.2017.]

Ministère de l'Éducation nationale (2010), Programme d'enseignement obligatoire au choix d'arts en classe de première littéraire, d'enseignement de spéci- 
alité au choix d'arts en classe terminale littéraire et d'enseignement facultatif d'arts au cycle terminal des séries générales et technologiques, Paris: Ministère de l'Éducation nationale. Dostupno na: http://www.education.gouv.fr/cid53325/mene1019677a.html [7. 2. 2017.]

Ministrstvo za izobraževanje, znanost in šport (1999), Učni načrt za Glasbeni jezik, Ljubljana: Ministrstvo za izobraževanje, znanost in šport RS. Dostupno na: http://eportal.mss.edus.si/msswww/programi2013/programi/gimnazija/ gimnazija/glasbeni-jezik.htm [25. 10. 2016.]

Ministrstvo za izobraževanje, znanost in šport (2004), Učni načrt za Glasbenu vzgoju, Ljubljana: Ministrstvo za izobraževanje, znanost in šport RS. Dostupno na: http://www.mss.gov.si/fileadmin/mss.gov.si/pageuploads/podrocje/os/devetletka/predmeti_obvezni/Glasbena_vzgoja_obvezni.pdf [25.11.2016.]

Ministrstvo za izobraževanje, znanost in šport (2010), Učni načrt za gimnazije, Ljubljana: Ministrstvo za izobraževanje, znanost in šport RS. Dostupno na: http://portal.mss.edus.si/msswww/programi2010/programi/gimnazija/ucni nacrti.htm [25. 10.2016.]

Ministarstvo obrazovanja, znanosti, kulture i športa (2013), Nastavni plan i program na hrvatskome jeziku za gimnazije u Bosni i Hercegovini za Kanton Središnja Bosna, Travnik: Ministarstvo obrazovanja, znanosti, kulture i športa. Dostupno na: http://www.mozks-ksb.ba/Dokumenti/OpciDokumenti/Nastav ni\%20plan\%20i\%20program\%20na\%20hrvatskome\%20jeziku\%20za\%20gi mnazije $\% 20 \% 20 u \% 20$ Bosni\%20i\%20Hercegovini.pdf [16. 3. 2017.]

Ministry of Education and Culture (2007), Hungarian National Core Curriculum, Budapest: Ministry of Education and Culture. Dostupno na: http://www.nefmi.gov.hu/english/hungarian-national-core [16. 3. 2017.]

Mrnjaus, Kornelija i Rončević, Nena (2012), »Interkulturalna osjetljivost i interkulturalne kompetencije budućih pedagoga, odgajatelja, učitelja i nastavnika - studenata Sveučilišta u Rijeci«, u: Hrvatić, Neven i Klapan, Anita (ur.), Pedagogija i kultura: teorijsko-metodološka određenja pedagogijske znanosti, Zagreb: Hrvatsko pedagogijsko društvo, str. 314-321.

[MZOS] Ministarstvo znanosti, obrazovanja i sporta RH (1994), Nastavni program Glazbene umjetnosti, Zagreb: Ministarstvo prosvjete i kulture RH.

[MZOS] Ministarstvo znanosti, obrazovanja i sporta RH (2006), Nastavni plan i program za osnovnu školu, Zagreb: Ministarstvo znanosti, obrazovanja i sporta RH.

[MZOS] Ministarstvo znanosti, obrazovanja i sporta RH (2011), Nacionalni okvirni kurikulum za predškolski odgoj i obrazovanje te opće obvezno i srednjoškolsko obrazovanje, Zagreb: Ministarstvo znanosti, obrazovanja i sporta RH.

Previšić, Vlatko (1987), »Interkulturalizam u odgoju evropskih migranata«, $\mathrm{Na}$ predak, 42(3), str. 304-313. 
Previšić, Vlatko (1999), »Učitelj - interkulturalni medijator«, u: Rosić, Vladimir (ur.), Nastavnik - čimbenik kvalitete u odgoju i obrazovanju, Rijeka: Filozofski fakultet u Rijeci, str. 78-84.

Previšić, Vlatko (2009), »Interkulturalna obzorja suvremene škole«, u: Puževski, Valentin i Strugar,Vladimir (ur.), Škola danas za budućnost, Križevci, Bjelovar: HPKZ, str. 13-28.

Research Institute of Education in Prague (2007), Framework Educational Programme for Basic Education, Prague: Research Institute of Education in Prague. Dostupno na:

http://www.msmt.cz/areas-of-work/basic-education-1 [16. 3. 2017.]

Sablić, Marija (2011), »Interkulturalni kurikulum - osvrti i perspektive«, Pedagogijska istraživanja, 8(1), 125-138.

Senatsverwaltung für Bildung, Jugend und Sport (2006), Rahmenlehrplan Musik-

Sekundarstufe II, Berlin: Senatsverwaltung für Bildung, Jugend und Sport. Dostupno na: https://www.berlin.de/sen/bildung/unterricht/faecher-rahmenlehrplaene/ rahmenlehrplaene/ [8.3. 2017.]

Southcott, Jane i Joseph, Dawn (2010), »Engaging, exploring, and experiencing multicultural music in Australian music teacher education: The changing landscape of multicultural music education «, Journal of Music Teacher Education, 20(1), str. 8-26. doi: http://dx.doi.org/10.1177/1057083710362461

Staatsministerin für Unterricht und Kultus (2004), Mittelschule, genehmigter Lehrplan, München: Staatsministerin für Unterricht und Kultus. Dostupno na: https://www.isb.bayern.de/mittelschule/lehrplan/mittelschule/ [3. 3. 2017.]

Ščedrov, Ljiljana i Marić, Saša (2007a), Glazbena petica, Zagreb: Profil.

Ščedrov, Ljiljana i Marić, Saša (2007b), Glazbena sedmica, Zagreb: Profil.

Ščedrov, Ljiljana i Marić, Saša (2007c), Glazbena osmica, Zagreb: Profil.

Tarman, Ilknur i Tarman, Bülent (2011), »Developing effective multicultural practices: A case study of exploring a teacher's understanding and practices «, The Journal of International Social Research, 17(4), str. 578-598. Dostupno na: http://www.sosyalarastirmalar.com/cilt4/sayi17pdf/5egitim/tarman_ilknur bulent.pdf [7. 12. 2016.]

Wang, Jui-Ching i Humphreys, T. Jere (2009), »Multicultural and popular music content in an American music teacher education program «, International Journal of Music Education, 27(1), str. 19-36.

doi: http://dx.doi.org/10.1177/0255761408099062

Weidknecht, Marguerite K. (2009), »Multicultural music education: Building an appreciative audience«, Annual Meeting of the American Educational Research Association, San Diego, CA, str. 19. Dostupno na:

http://files.eric.ed.gov/fulltext/ED506352.pdf [25. 2. 2017.] 


\title{
Izvori s interneta
}

meNet. Music Education in Italy. Dostupno na:

http://menet.mdw.ac.at/menetsite/english/topics.html?m=1\&c=0\&lang=en [22. 11.2016.]

meNet. Music Education in Slovenia. Dostupno na:

http://menet.mdw.ac.at $/$ menetsite/english/topics.html? $\mathrm{m}=1 \& \mathrm{c}=0 \&$ lang=en [22. 11.2016.]

meNet. Music Education in the United Kingdom. Dostupno na:

http://menet.mdw.ac.at/menetsite/english/topics.html?m=1\&c=1\&zusatz=at \&lang=en [22. 11.2016.]

\section{INTERCULTURAL CONTENTS AS A FOUNDATION OF TEACHING MUSIC IN EUROPEAN GENERAL EDUCATION SCHOOLS}

\author{
Amir Begić, Jasna Šulentić Begić
}

The development of intercultural competencies of an individual has become a necessity, and a contemporary school has to keep up with time and events we are surrounded with. The education of a young person capable of working effectively and living in a modern society also implies the development of the intercultural competence of each student. Music education is certainly an area in which the intercultural competence of students can be developed. The precondition is an intercultural conceptual curriculum, intercultural contents in textbooks, as well as examples of different musical traditions from all continents for listening to music. Therefore, the aim of this paper was to determine whether national, subject, and school curricula, as well as the content of textbooks and related CDs are based on interculturalism in twelve European countries (Croatia, Hungary, Slovenia, Austria, Germany, Czech Republic, Switzerland, Italy, Bosnia and Herzegovina, France, England and Finland). The results of the research have shown that the teaching of music, especially in the grammar school, is still insufficiently focused on introducing music of different cultures, which is a major obstacle to the intercultural education of students that we must strive for.

Key words: intercultural education, music education, elementary school, grammar school, curriculum 